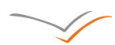 \\ VERSIT^ 10.2478/auoc-2013-0008 \\ Ovidius University Annals of Chemistry \\ Volume 24, Number 1, pp.39-42, 2013
}

\title{
Trace element levels of three mushroom species
}

\author{
Simona DOBRINAS, Alina SOCEANU*, Gabriela STANCIU, Viorica POPESCU \\ and Luiza Georgiana ARNOLD
}

\begin{abstract}
Department of Chemistry and Chemical Engineering, Faculty of Physics, Chemistry, Electronics and Petroleum
\end{abstract} Tehnology, Ovidius University, Constanta 900524, Romania

\begin{abstract}
The aim of this study was to determine $\mathrm{Cu}, \mathrm{Fe}$ and $\mathrm{Cr}$ contents of three species of fresh mushrooms and canned mushrooms: white and brown champignon (Agaricus bisporus) and Pleurotus Ostreatus. Were analyzed various plant parts: stem, cap and cuticle of fresh mushrooms and only stem and cap for canned mushrooms. The levels of trace metals of mushroom samples collected from regions of Romania, Poland and Turkey were determined by UV/Visible spectrometry - standard addition method after digestion method. The contents of investigated trace metals in mushroom samples were found to be in the range of $0.01-2.26 \mathrm{mg} / \mathrm{Kg}$ for chromium, $2.02-430.67 \mathrm{mg} / \mathrm{Kg}$ for copper and $240.40-7952.89 \mathrm{mg} / \mathrm{Kg}$ for iron. The iron content was found to be higher than those of the other two minerals in all the samples. Mushrooms species in the highest levels of trace elements were found white champignon for $\mathrm{Cu}$ and $\mathrm{Fe}$ and brown champignon for $\mathrm{Cr}$.
\end{abstract}

Keywords: $\mathrm{Cu}, \mathrm{Fe}, \mathrm{Cr}$, mushrooms, UV/VIS spectrometry.

\section{Introduction}

The heavy metal pollution represents a significant environmental problem arising from its toxic effects and accumulation throughout the food chain. Accurate and adequate food composition data are invaluable for estimating the adequacy of intakes of essential nutrients and assessing exposure risks from intake of toxic non-essential heavy metals.

Mushrooms have been reported as therapeutic foods, useful in preventing diseases such as hypertension, hypercholesterolemia and cancer. These functional characteristics are mainly due to their chemical composition [1, 2].

Mushrooms are valuable healthy and nutritious foods, good source of quality protein, minerals and vitamins, low in calories and have been relished as a delicacy for centuries because of their subtle flavor, nice aroma and physical taste appeal [3-5].

Copper is an essential metal for normal plant growth and development, although it is also potentially toxic. For humans copper is an essential nutrient that plays a role in the production of hemoglobin (the main component of red blood cells), myelin (the substance that surrounds nerve fibers), collagen (a key component of bones and connective tissue), and melanin (a dark pigment that colors the hair and skin). The RDA (Recommended Dietary Allowance) for copper - is 900 micrograms a day for both men and women.

Iron is critical for cholorphyll formation and photosynthesis. Iron is also used by enzymes to regulate transpiration in plants. For humans, iron is a mineral present in certain enzymes and hemoglobin, the substance in red blood cells that enables the blood to transport oxygen throughout the body. The RDA for iron for the adult male is $10 \mathrm{mg} / \mathrm{day}$, while that for the adult woman is $15 \mathrm{mg} /$ day $[6,7]$.

Chromium can be considered even a trace element, but in excessive dose is a toxic for health. Toxicity of $\mathrm{Cr}$ depends on its valence state: $\mathrm{Cr}(\mathrm{VI})$ is highly toxic and mobile whereas $\mathrm{Cr}$ (III) is less toxic $[8,9]$.

Mushrooms can build up large concentrations of some heavy metals, such as lead, cadmium and mercury, and a great effort has been made to evaluate the possible danger to human health from the ingestion of mushrooms [10-13]. 
The aim of this study was to determine $\mathrm{Cu}, \mathrm{Fe}$ and $\mathrm{Cr}$ contents of three species of fresh and canned mushrooms.

\section{Experimental}

\subsection{Reagents and solutions}

The working solutions were prepared by diluting the stock solutions to appropriate volumes. All reagents were of analytical-reagent grade and all solutions were prepared using deionised water.

\subsection{Sample preparation}

Studied samples in this paper were white and brown champignons (Agaricus bisporus) from Romania and Poland (fresh and canned mushrooms) and from Turkey (fresh mushrooms) and Pleurotus Ostreatus (fresh mushrooms). Were analyzed various mushroom parts: stem, cap and cuticle of fresh mushrooms and only stem and cap for canned mushrooms.

The determination of the total metal concentration in the investigated samples was done after sample mineralization step using a Digesdahl device.

\subsection{Sample analysis}

Standard addition was the method used to determinate the $\mathrm{Cu}, \mathrm{Fe}$ and $\mathrm{Cr}$ concentration in mushroom samples.

Ammonia is a very sensitive reagent used in the analysis of copper. The method is based on the reaction of $\mathrm{Cu}$ (II) with ammonia and spectrometric determination of the complex $\left[\mathrm{Cu}\left(\mathrm{NH}_{4}\right)\right]^{2+}$, using two solutions: A and B.

\section{Solution A:}

- In a $50 \mathrm{~mL}$ volumetric flask, $5 \mathrm{~mL}$ sample and 2.5 $\mathrm{mL}$ ammonia were added and the volume was diluted with distilled water;

- the absorbance was read at $600 \mathrm{~nm}$ at the DR 2000 spectrometer using a reference solution (distilled water).

\section{Solution B:}

- In another flask, $5 \mathrm{~mL}$ sample solution, $2 \mathrm{~mL}$ standard $\mathrm{Cu}$ (II) reagent and all reagents from $\mathrm{A}$ solution in the presented order were added;

- Solution B absorbance was read against distilled water.

For iron determination have been prepared two solutions A and B. Solution A contains only unknown sample and solution B unknown sample and a measured volume of standard solution of $\mathrm{Fe}$ (II).

\section{Solution A:}

- In a $50 \mathrm{~mL}$ volumetric flask, $2 \mathrm{~mL}$ sample, $5 \mathrm{~mL}$ sodium acetate and $5 \mathrm{~mL}$ of hydroxylamine hydrochloride were added and were shaked for mixing;

- after 5 minutes were added $5 \mathrm{~mL}$ of 1.10 phenanthroline reagent;

- after 10 minutes for stabilizing color, the volume was diluted with distilled water;

- the absorbance was read at $510 \mathrm{~nm}$ at the DR 2000 spectrometer using a reference solution (distilled water).

\section{Solution B:}

- In another flask, $2 \mathrm{~mL}$ sample solution, $2 \mathrm{~mL}$ standard $\mathrm{Fe}$ (II) reagent and all reagents from $\mathrm{A}$ solution in the presented order were added;

- Solution B absorbance was read against distilled water.

For $\mathrm{Cr}$ determination two solutions $\mathrm{A}$ and $\mathrm{B}$ have been prepared. Solution A contains only unknown sample and solution B unknown sample and a measured volume of standard solution of $\mathrm{Cr}$ (VI). The method is based on the determination of total chromium in form of $\mathrm{Cr}$ (VI) with 1.5 diphenylcarbazide after complete oxidation of $\mathrm{Cr}$ (III) to $\mathrm{Cr}$ (VI) with $\mathrm{H}_{2} \mathrm{O}_{2}$.

\section{Solution A:}

- In a $50 \mathrm{~mL}$ volumetric flask, $5 \mathrm{~mL}$ sample, $0.5 \mathrm{~mL}$ $\mathrm{H}_{2} \mathrm{O}_{2}, \quad 0.2 \quad \mathrm{~mL} \quad \mathrm{H}_{2} \mathrm{SO}_{4}$ and $2 \mathrm{~mL}$ of 1.5 diphenylcarbazide were added and were shaked for mixing;

- the volume was diluted with distilled water;

- the absorbance was read at $540 \mathrm{~nm}$ at the DR 2000 spectrometer using a reference solution (distilled water).

\section{Solution B:}

- In another $50 \mathrm{~mL}$ volumetric flask, $5 \mathrm{~mL}$ sample solution $1 \mathrm{~mL}$ standard $\mathrm{K}_{2} \mathrm{Cr}_{2} \mathrm{O}_{7}$ solution and all reagents from $\mathrm{A}$ solution in the presented order were added;

- Solution B absorbance was read against distilled water.

\section{Results and Discussions}

The results of trace metals determination are presented in Tables 1-6. 
Table 1. The content of $\mathrm{Cu}$ in fresh mushroom samples, $\mathrm{mg} / \mathrm{kg}($ mean $\pm \mathrm{SD})$

\begin{tabular}{|c|l|l|l|l|}
\hline \multicolumn{2}{|c|}{ Samples } & Stem & Cup & Cuticle \\
\hline \multirow{2}{*}{$\begin{array}{c}\text { White } \\
\text { Agaricus } \\
\text { bisporus }\end{array}$} & Romania & $12.3 \pm$ & $15.7 \pm$ & $38.7 \pm$ \\
& & 0.6 & 0.8 & 2.3 \\
\cline { 2 - 5 } & Poland & $123 \pm$ & $130.7 \pm$ & $203.3 \pm$ \\
& & 6.1 & 9.1 & 10.1 \\
\cline { 2 - 5 } & Turkey & $89.6 \pm$ & $20.3 \pm$ & $460.3 \pm$ \\
& 4.9 & 1.2 & 27.6 \\
\hline \multicolumn{2}{|c|}{ Pleurotus } & $37.6 \pm$ & $8.9 \pm$ & $36.7 \pm$ \\
& 2.6 & 0.4 & 2.6 \\
\hline \multicolumn{2}{|c|}{ Brown Agaricus } & $2 \pm$ & $96.6 \pm$ & $292.2 \pm$ \\
\multicolumn{2}{|c|}{ bisporus } & 0.1 & 5.7 & 17.5 \\
\hline
\end{tabular}

Table 2. The content of $\mathrm{Cu}$ in canned mushroom samples, $\mathrm{mg} / \mathrm{kg}$ (mean $\pm \mathrm{SD})$

\begin{tabular}{|c|c|c|c|}
\hline \multicolumn{2}{|c|}{ Samples } & Stem & Cup \\
\hline White & Romania & $48.4 \pm 2.4$ & $53.2 \pm 3.7$ \\
\hline $\begin{array}{l}\text { Agaricus } \\
\text { bisporus }\end{array}$ & Poland & $134.7 \pm 7.4$ & $165.2 \pm 8.2$ \\
\hline
\end{tabular}

The largest amount of copper was found in cuticle of white mushroom from Turkey. White mushrooms has a higher concentration of copper than brown. Copper concentration ranges from 2.02 to $460.37 \mathrm{mg} / \mathrm{kg}$. Literature were reported copper concentrations ranging from 6.20 to $480 \mathrm{mg} / \mathrm{kg}$ [13]. In all samples analyzed copper concentration was comparable to that reported in the literature. From Tables 1 and 2 it was observed that the concentration levels of copper in canned mushrooms were higher than copper concentrations in fresh mushrooms.

Table 3. The content of $\mathrm{Fe}$ in fresh mushroom samples, $\mathrm{mg} / \mathrm{kg}$ (mean $\pm \mathrm{SD})$

\begin{tabular}{|c|c|c|c|c|}
\hline \multicolumn{2}{|c|}{ Samples } & Stem & Cup & Cuticle \\
\hline White & Romania & $240.4 \pm$ & $320.2 \pm 16.1$ & $7952.8 \pm$ \\
Agaricus & & 14.4 & & 477.1 \\
\cline { 2 - 5 } bisporus & Poland & $272.2 \pm$ & $529.1 \pm 31.7$ & $1553.5 \pm$ \\
& & 13.6 & & 124.2 \\
\cline { 2 - 5 } & Turkey & $1220.4 \pm$ & $420.4 \pm 21.1$ & $6718.1 \pm$ \\
& & 109.8 & & 470.2 \\
\hline \multicolumn{2}{|c|}{ Pleurotus } & $561.1 \pm$ & $652.7 \pm 39.1$ & $2207 \pm$ \\
\multicolumn{2}{|c|}{ Brown Agaricus } & 28.1 & & 110.3 \\
bisporus & $1561.5 \pm$ & $1470.8 \pm 88.2$ & $5950.1 \pm$ \\
\multicolumn{2}{|c|}{} & & & 357.1 \\
\hline
\end{tabular}

The highest concentration of total iron was found in white Romania mushroom cuticle. Iron concentration has ranged between 240.4 to 7952.8 $\mathrm{mg} / \mathrm{kg}$. In the literature have been reported iron concentrations ranging from 56.1 to $7162 \mathrm{mg} / \mathrm{kg}$ [13].

Table 4. The content of Fe in canned mushroom samples, $\mathrm{mg} / \mathrm{kg}$ (mean $\pm \mathrm{SD})$

\begin{tabular}{|c|c|c|c|}
\hline \multicolumn{2}{|c|}{ Samples } & Stem & Cup \\
\hline \multirow{2}{*}{$\begin{array}{c}\text { White } \\
\text { Agaricus } \\
\text { bisporus }\end{array}$} & Romania & $240.4 \pm 19.2$ & $320.2 \pm 25.6$ \\
\cline { 2 - 4 } & Poland & $272.2 \pm 16.3$ & $529.1 \pm 37.1$ \\
\hline
\end{tabular}

Table 5. The content of $\mathrm{Cr}$ in fresh mushroom samples, $\mathrm{mg} / \mathrm{kg}$ (mean $\pm \mathrm{SD}$ )

\begin{tabular}{|c|c|c|c|c|}
\hline \multicolumn{2}{|c|}{ Samples } & Stem & Cup & Cuticle \\
\hline White & Romania & $0.030 \pm$ & $0.20 \pm$ & $1.30 \pm$ \\
Agaricus & & 0.002 & 0.01 & 0.07 \\
\cline { 2 - 5 } bisporus & Poland & $0.100 \pm$ & $0.20 \pm$ & $0.080 \pm$ \\
& & 0.008 & 0.01 & 0.004 \\
\cline { 2 - 5 } & Turkey & $0.100 \pm$ & $0.100 \pm$ & $0.080 \pm$ \\
& & 0.007 & 0.005 & 0.007 \\
\hline \multicolumn{2}{|c|}{ Pleurotus } & $0.0100 \pm$ & $0.100 \pm$ & $1.8 \pm$ \\
\multicolumn{2}{|c|}{ Brown Agaricus } & 0.0009 & 0.006 & 0.1 \\
\hline \multicolumn{2}{|c|}{ bisporus } & $0.30 \pm$ & $0.40 \pm$ & $2.2 \pm$ \\
\hline
\end{tabular}

Table 6. The content of $\mathrm{Cr}$ in canned mushroom samples, $\mathrm{mg} / \mathrm{kg}$ (mean $\pm \mathrm{SD})$

\begin{tabular}{|c|c|c|c|}
\hline \multicolumn{2}{|c|}{ Samples } & Stem & Cup \\
\hline White \\
$\begin{array}{c}\text { Agaricus } \\
\text { bisporus }\end{array}$ & Romania & $0.100 \pm 0.007$ & $0.20 \pm 0.01$ \\
\cline { 2 - 4 } & Poland & $0.100 \pm 0.006$ & $0.4 \pm 0.03$ \\
\hline
\end{tabular}

The largest amount of chromium was found in Pleurotus cuticle. The smallest quantity of chromium was found in white Romania mushroom stem. Chromium concentration has values between 0.011 to $2.26 \mathrm{mg} / \mathrm{kg}$. Literature were reported concentrations ranging from 0.3 to $10.88 \mathrm{mg} / \mathrm{kg}$ [10, 13]. Analyzed samples are lower chromium concentrations with those reported in the literature. From Tables 5 and 6 it was observed that the concentration levels of chromium in canned mushrooms were higher than chromium concentrations in fresh mushrooms. 


\section{Conclusions}

Analyzed mushroom species contain appreciable quantities of $\mathrm{Fe}, \mathrm{Cu}$ and $\mathrm{Cr}$. Champignon brown variety has a higher amount of chromium in comparison with white Pleurotus variety. Champignon white mushrooms have a higher copper concentration than brown. Variety of white Romanian champignon has the lowest concentration of copper in comparison with other countries. Brown mushrooms have a higher concentration of iron than white, except cuticle species in Romania.

The concentrations of copper, chromium and total iron in canned mushrooms are higher than in fresh mushrooms probably due to accumulation of metals in tin case.

\section{References}

* E-mail address: asoceanu@ univ-ovidius.ro

[1]. Y.K. Bayhan, B. Keskinler, A. Cakici, M. Levent and G. Akay, Water Res., 35 (9), 2191 (2001).

[2]. M. Tuzen, E. Sesli and M. Soylak, Food Control, 18, 806 (2007).

[3]. S.M. Sabir, I. Hayat, I. Hussain and S.R. Ali, Pakistan Journal of Plant Pathology 2(2), 97 (2003).

[4]. P. Ouzouni and Riganakos K.A., Acta Alimentaria 36, 99 (2007).
[5]. P. Ouzouni, P.G. Veltsistas, E. Paleologos and K.A. Riganakos, Journal of Food Composition and Analysis 20(6), 480, (2007).

[6]. Y. Inmaculada, Braz. J. Plant Physiol. 17, 1 (2005)

[7]. R. Anthony Brach, "Critical for chlorophyll formation and photosynthesis. Important in enzyme systems and respiration in plants." http://www.agric.gov.ab.ca/agdex/500/5313.html

[8]. A. K. Shanker, C. Cervantes, H. Loza-Tavera and S. Avudainayagam, Environment International 31(5), 739 (2005)

[9]. A. Soceanu, S. Dobrinas, V. Popescu, S. Birghila and V. Magearu, Ovidius University Annals of Chemistry, 17(1), 79 (2006)

[10]. D. Mendil, O. D. Uluozlu, E. Hasdemir and A. Caglar, Food Chemistry 88, 281 (2004).

[11]. A. Demirbas, Food Chemistry 74, 293 (2001).

[12]. H. Genccelep, Y. Uzun, Y. Tuncturk and K. Demirel Food Chemistry, 113, 1033 (2009)

[13]. M. Yamaç, D. Yildiz, C. Sarikürkü and M. Çelikkollu Food Chemistry, 10, 263 (2007).

Submitted: April $17^{\text {th }} 2013$ Accepted in revised form: May $11^{\text {th }} 2013$ 